\title{
Islamic Banks' Financing and Employment Generation: The Case of Punjab, Pakistan
}

\author{
Arshad Mahmood Malik ${ }^{1 *}$, Bilal Ashraf ${ }^{2}$ \\ ${ }^{1}$ Assistant Professor, Department of Economics, PMAS-Arid Agriculture University, Rawalpindi, Pakistan \\ ${ }^{2}$ Assistant Registrar, University of Gujrat, Gujrat, Pakistan
}

\section{Keywords}

Assets Formation

SME's, Employment Generation

Islamic Banks

Pakistan

Received: 17 May 2019

Accepted: 20 June 2019

\begin{abstract}
The objective of this study is to assess the impact of Islamic financing modes on employment through asset formation and value creation of Islamic Banking in Punjab, Pakistan. Data was collected from two randomly selected Islamic Banks in Pakistan namely Meezan Bank and Al-Baraka Bank (Pakistan) Ltd. Multistage sampling procedure was used for selection of sample respondents from three regions of Punjab. List frame of the study consisted of respondents/firms utilizing finance from selected Islamic Banks located in each district. The sample of the study comprised of 206 small and medium firms who utilized Islamic modes of financing to get financing for their business. Variables of the model comprised of employment generation, asset formation, technology, firm age and business size. Least square regression model was used for analysis of the cross sectional data. All the independent variables of the model have significant effect on dependent variable. Empirical results revealed that only asset formation has direct relationship with employment generation. Technology, firm age and business size have inverse relationship with employment generation capacity of the borrowing firms utilizing Islamic finance. The study concluded that in Pakistan, the SME's used financing tool to enhance the assets by adopting the technological change. The results of the study will support policy makers, practitioners and planners to make more informed business decisions.
\end{abstract}

KAUJIE Classification: I23, L25

JEL Classification: G21, D63

(c) 2019 JIBM. All rights reserved.

\section{INTRODUCTION}

Islamic finance is operated through the fundamental laws of Shari'ah that pertain to the principles laid down in Holy Qur'ān and the Sunnah of the holy Prophet (PBUH). The theoretical structure of Islamic finance guides the people to make their economic choices according to the core tenets of the Shari'ah. Iqbal and Tsubota (2006) emphasized that the

\footnotetext{
* Corresponding author: Arshad Mahmood Malik

†Email: khurram.shahzad@riphah.edu.pk
} 
core of Islamic financial system is the prohibition of interest, while the other principles and doctrines of Islam suggest sharing of loss and profits, promotion of joint businesses and discouragement of speculative behavior.

Many Muslims and non-Muslims scholars and philosophers have investigated the principles of Islamic Finance (Ajaga and Nunnenkamp, 2008; Usmani, 2007). Following are the general principles of Islamic Finance: (i) the prohibition of riba (usury or interest) (ii) the prohibition of gharar (uncertainty about the subject matter, price and delivery in the contracts) and Gambling (maysir and other games of chance) (iii) risk not to be separated from the ownership (iv) Observing ethical and moral values in business transactions (v) Prohibition of short selling (except with conditions of salam sale); and (vi) transparency and disclosure. The main contracts and instruments available in Islamic finance are mushārakah, mudāarabah, diminishing mushārakah, ijārah, murābahah, salam, istisna $\bar{a}^{\prime}$, Islamic Investment Fund and ijärah (Usmani, 2007). Based on the above features, Islamic banking and finance system has the capacity of promoting investments in real production and business sectors in any economy. Thereby, Islamic financial institutions can be instrumental in socioeconomic development by providing finance to micro businesses (Ayub, 2018).

State Bank of Pakistan's Vision 2020 (2016-20) emphasized on enabling and promoting Islamic Banks in Pakistan (Government of Pakistan, 2017). Performance of Islamic banking Industry is exceptional in Pakistan due to its high growth during last few years which is growing at a pace of fifteen percent per annum (Government of Pakistan, 2018) due to investment of federal government in ijārah șukuk and other Sharī' ah compliant instruments. The contribution of both muräbahah and diminishing mushärakah in the IBI was 56.3 percent in 2015, but subsequently their share declined, while the share of mushärakah (Running Finance) increased (Government of Pakistan, 2016). In 2016, all mode of Islamic financing experienced increasing trend excluding murābahah, salam and istisna $\bar{a}^{`}$ (Government of Pakistan, 2017). The assets and deposits of IBI reached to 13.5 and 15.5 percent of the overall banking industry after its re-launch in 2001-02 with 22 Islamic Banking Institutions in the country in 2018 (Government of Pakistan, 2019).

\section{Islamic banks and Employment Generation}

Many studies investigated the role of financial sector on unemployment and reported mixed impact. Conventional financial sector has no significant impact on unemployment in emerging economies (Bayar, 2016). In developing economies like Nigeria, financial credit extension has significant effect on reducing unemployment (Aliero, Ibrahim, \& Shuaibu, 2013). When unemployment increased, financial sector contracted (Effendi, \& Yuniarti, 2018). In Pakistan, it has been reported that financial accommodation to the private sector improves employment rate (Shabbir, Anwar, Hussain, \& Imran, 2012). Other factors effecting unemployment are rigid market regulations (Kim, Chen, \& Lin, 2018) and the tight monetary policy resulting in increasing cost of capital. (Christiano, Eichenbaum, \& Trabandt, 2016). Interest free monetary policy is proved to be better as compared to interest based policy (Selim, \& Hassan, 2019). 
The productivity of labor force plays an important role in economic development and growth by pushing the efficiency and competitiveness. According to the Labour Force Statistics, total labour force of Pakistan was 61.04 million from which 94 percent were employed and 6 percent were unemployed during 2014-15 (Government of Pakistan, 2018). Out of this, the total labour force in Punjab Pakistan was 35.71 million; 93.67 percent employed and 6.33 percent were unemployed.

The government of Pakistan has adopted the strategic polices such as sectoral development plan, employment promotion polices, micro credit and Islamic finance facilitation through different institutions like National Internship Program (NIP), Overseas Employment and Pakistan Skill Development Programme to increase the employment opportunities and growth in the labour market (Government of Pakistan, 2014).

Employment also depends on the size of the firms and in this context the SMEs have been considered as the most suitable structure to provide employment, particularly in countries with abundant labour force (Zafar \& Mustafa, 2017). Number of studies emphasized on relationship of firm age, size (Birch, 1981) and growth (Banerjee, 2014; 2016) in different countries of the world. In most of the studies, inverse relationship was found between firm age and employment while very few argued positive relationship based on entry of new firms. This argument was based on the notion that new/entering firms grow faster than older firms.

Keeping in view these aspects, the resent study was planned to investigate the role of Islamic finance extended by Islamic banks on employment generation in Pakistan.

\section{DATA AND METHODS}

\section{Study Area}

Punjab is the Pakistan's most populous province with a population exceeding 82 million, approximately $56 \%$ of the country's total population. Punjab has the largest economy, contributing to the country's GDP. Punjab province comprised of 36 districts constituting four regions such as Southern region, Northern region, Central Region and Western region (Government of Pakistan, 2015).

TABLE 1

Sample Selection and Distribution of the Study

\begin{tabular}{|c|c|c|c|c|c|c|}
\hline \multirow[t]{2}{*}{ Regions } & \multirow{2}{*}{$\begin{array}{l}\text { Selected } \\
\text { Districts }\end{array}$} & \multicolumn{2}{|l|}{ Population size } & \multicolumn{2}{|l|}{ Sample size } & \multirow[t]{2}{*}{ Total } \\
\hline & & Meezan Bank & Al Barka Bank & Meezan Bank & Al Barka Bank & \\
\hline $\begin{array}{l}\text { Southern } \\
\text { Punjab }\end{array}$ & Bahawalnagar & 80 & 55 & 54 & 42 & 96 \\
\hline Northern & Gujrat & 45 & 30 & 42 & 28 & 70 \\
\hline $\begin{array}{l}\text { Central } \\
\text { Punjab }\end{array}$ & Lahore & 250 & 150 & 12 & 28 & 40 \\
\hline
\end{tabular}

Source: (https://bit.ly/2n4a00z) 
Targeting all four regions of Punjab, for sample selection was difficult due to limited time and lack of resources. Hence, three regions of Punjab were selected randomly, i.e., Northern, Southern and Central Punjab. Further, one district from each region was selected randomly. Gujrat was selected from Northern region as its boundary is adjacent to Northern region of Punjab. District Lahore and Bahawalnagar were selected from Central and Southern Punjab respectively for data collection. The sampling procedure of each selected region is given in Table 1.

\section{Selection of Banks and Respondents}

Out of the five full-fledged Islamic banks, two banks were selected using simple random sampling technique, namely Meezan Bank and Al-Barka Bank. Primary data were collected from the sample of 206 clients who got financing, using multistage purposive sampling technique from all mentioned regions with 108 clients of Meezan Bank and 98 clients of Al Baraka Bank from selected three districts. The list of clients/borrowers and other necessary information were collected from related branches of Meezan Bank and Al Baraka Bank in the respective regions.

\section{Questionnaire Development and Pretesting}

Primary data of the study was collected through a well-structured questionnaire including important parameters of labour and the credit profile of borrowers. Questionnaire was shared with other researchers and faculty members of different universities for guidance and further improvement. Questionnaire was pretested in Gujrat district from 5 respondents and further improved and finalized in the light of pretested results.

\section{Data Analysis and Model Formulation}

Data collected from the respondents was arranged and checked for possible outliers. Raw data was imported to Statistical Package for Social Sciences (SPSS) version 21.0 for further analysis. Researchers used the descriptive statistics to analyze the data including frequencies, means and standard deviation of demographic variables.

Employment generation depends mainly on success of a business. Major indictors of a successful business are "assets formation", "business experience" (Nunley, Pugh, Romero, \& Seals 2016), "Technology" (Schmitz, 2018) and "Business Size" (Atkinson, \& Storey, 2016; Birch 1981; Liu, 2018). Employment model used the employment generation as dependent variable for analyzing the effect of independent variables of the model. Error term is used to capture the remaining effects, and measures the impact of all controlled variables on employment generation.

$$
\mathrm{EG}=\beta_{0}+\beta_{1} \mathrm{AF}+\beta_{2} \mathrm{FA}+\beta_{3} \mathrm{~T}+\beta_{4} \mathrm{BS}+\varepsilon
$$

Where

$\beta_{0}=$ Constant

$\mathrm{EG}=$ Employment Generation

$\mathrm{AF}=$ Assets Formation 
$\mathrm{T}=$ Technology

FA $=$ Firm Age (Experience)

$\mathrm{BS}=$ Business Size

\section{RESULTS AND DISCUSSION}

\section{Gender Information of Respondents}

The selected respondents of the study from selected districts comprised 194 persons out of which 94 percent were male and 6 percent were female respondents. The gender distribution of respondents indicated the access of male members of the society to credit market (Kimuyu \& Omiti, 2000). The female members have poor access to the credit market in the study area.

\section{Education Level of Respondents}

Education is the primary tool for the growth and development of the economy, social welfare and the basic human right for all people of a country. Literacy rate in urban areas of Pakistan is 74 percent and in rural area 49 Percent. Provincial achievement in literacy rate indicated that Punjab has 61 percent literate population, while Sindh, Khyber Pakhtunkhwa and Baluchistan have 56\%, 53\% and 43\% literate population respectively (PSLM, 2013-14). Intangible capital like education always supports in improving investment opportunities (Peters \& Taylor, 2017).

The educational picture of the respondents clearly disclosed that matriculation was the dominant feature of the borrowers. The educational distribution of the respondents represented that $16.5,12.6,32,14.1,14.6,5.34$ and 4.90 percent of the respondents had got primary education, middle, Matric, Intermediate, graduation, Master's degree (sixteen years of schooling) and higher (MS) education or technical education or diploma holders respectively. This also indicates that wide educational discrepancy is featured in the study area.

\section{Source of Initial Business Finance (Startup Grant)}

The capital is an essential factor of production, required for improving investment opportunity and enhancing efficiency in business. Capital markets in Pakistan played a vital role in mobilizing the domestic resources and efficient utilization of funds to enhance the productivity.

Out of total 206 respondents, 37.4\% used conventional bank loan as a source of capital to initiate their business, while only $1.5 \%$ of the respondents of Northern Punjab got funds/finance from money lender as startup capital. The activity of Micro Finance Institutions (MFI's) is very limited in the area.

\section{Registration of Business with Security Exchange Commission of Pakistan (SECP)}

Entrepreneurs are an important component of taxation system and feel displeasure from paying taxes due to lack of tax culture in the country. On the other hand entrepreneurs feel happy while enjoying public infrastructure developed through taxes paid (Aghion, Akcigit, 
Cagé, \& Kerr, 2016). Only 0.6 percent of the population pays taxes in Pakistan, 4.7 per cent in India, 58 per cent in France and 80 per cent in Canada (FBR, 2011).

With regard to the present study, $83 \%$ firms/respondents had not registered their business with any formal institutions, whereas only $17 \%$ firms had registered their business with SECP and were pay the taxes regularly. Taxpaying behavior of the respondents revealed that taxpaying is directly related with education level. More educated business owner, the more s/he paid tax; and the less educated owner paid less tax in the studied population.

\section{Length of Current Business}

Business experience and length of current business relate to each other and represent business specialization of the borrowers. The business experience of the firm owner or borrower was demonstrated in different regions and categorized into little experience $(<5$ years $)$, intermediate experience (5-10 years), experienced (10-20 years), specialized (20-30 years) and highly specialized ( $>30$ years) borrowers on the basis of length of current business which is used as proxy for experience (Table 2).

Little experienced borrowers comprised only $2.4 \%$ of the total respondents/firms and belonged to Gujrat district of Punjab probably due to late initiation of credit/financing schemes in the area. Intermediate experienced borrowers were $16 \%$ of the total respondents/firms. Among this category, 55, 45.4 and zero percent belong to Northern, Southern and Central region respectively. The experienced borrowers were comprised of 24.3 percent of total sample. With regard to the geographical distribution, majority were in Southern region of Punjab (46\%) followed by 28\% from Northern region and 26\% from Central Punjab.

Specialized borrowers (dominant proportion of borrowers) were 74 with their share of 36 percent in total. The specialized firm's owners were mainly centered in Southern region of Punjab with a share of 49 percent followed by 28 percent in Northern region and 26 percent in Central region.

Lastly, highly specialized borrowers constituted 44 (21\%) of the total respondents/firms and mainly gathered in $22(50 \%)$ in Southern region followed by $12(27.3 \%)$ in Northern region, and 10 (22.7\%) in Central region. They had more than 30 years of experience to start their business.

TABLE 2

Business Experience of Borrowers in Different Regions of Punjab

\begin{tabular}{llllll}
\hline \hline Category & Experience (years) & Number & Southern Punjab & Central Punjab & Northern Punjab \\
\hline $\begin{array}{l}\text { Little expe- } \\
\text { rienced }\end{array}$ & $<5$ & $5(2)$ & 0 & 0 & 5 \\
$\begin{array}{l}\text { Intermediate } \\
\text { experienced }\end{array}$ & $5-10$ & $33(16)$ & 15 & 0 & 18 \\
$\begin{array}{l}\text { Experienced } \\
\text { Specialized }\end{array}$ & $20-20$ & $50(24)$ & 23 & & \\
$\begin{array}{l}\text { Highly spe- } \\
\text { cialized }\end{array}$ & $>30$ & $74(36)$ & $36(49)$ & 13 & 14 \\
Total & $44(21)$ & $22(50)$ & $10(23)$ & $21(28)$ \\
\hline
\end{tabular}

Note: Figures in parenthesis are in percentage 


\section{Size of Business}

Proper size of business is a sufficient condition for the survival of a business when combined with other factors like technology, etc. (Mas-Verdú, Ribeiro-Soriano, \& Roig-Tierno, 2015). Size of firm is also linked with innovation in the business (Burns, 2016). Size of firm can be classified into two categories: small business with worth up to 10 million rupees; and the large business firms having business equity more than Rs. 10 million. Business worth included the current and fixed assets of the business/assets.

Data revealed that firms utilizing Islamic finance from the Islamic banks were more or less evenly distributed in both categories. Small business firms constitute 54.4 percent of the sample population having equity less than ten million rupees. Small enterprises were mainly present in Northern and Southern Punjab. Large business firms were slightly less than small firms in number and constituted 45.6 percent of the total. (Table 3). Southern Punjab shared major part of large business firms constituting fifty percent of the large business firms.

TABLE 3

Business Size of Firms in different Regions

\begin{tabular}{|c|c|c|c|c|c|c|}
\hline & & \multicolumn{3}{|l|}{ Regions } & \multirow[t]{2}{*}{ Total } & \multirow[t]{2}{*}{ Percent } \\
\hline & & Northern Region & Southern Region & Central Region & & \\
\hline Business & Small Business & 42 & 45 & 25 & 112 & $54 \%$ \\
\hline Size & Large Business & 28 & 51 & 15 & 94 & $45 \%$ \\
\hline Total & & 70 & 96 & 40 & 206 & \\
\hline
\end{tabular}

\section{Employment and Financing by Islamic Banks in Punjab, Pakistan}

Major determinants of employment generation include asset formation, technology, firm age and business size (Banerjee 2016; Adelino, \& Robinson, 2017; Liu, 2018). The multiple linear regression model has been used to find the empirical results of the model as in Eq-1. The estimated results of the model are given in Eq.2.

$$
\hat{E G}=6.205+0.481 A F-0.309 T-0.121 F A-0.201 B S
$$

The results of multiple linear regression model, suggested that the coefficient of fitted regression model (eq-2) i.e assets formation (AF), technology (T), firm age (FA) and business size (BS), is significant, with positive and negative signs (Table 3) according to expected hypothesis whereas employment generation is the dependent variable.

Assets formation is statistically significant $(p<0.01)$ and strongly affects the employment generation. Therefore, increase in assets formation due to Islamic finance has significant and positive impact on employment generation as shown in Table 3.

Technology is also statistically significant and inversely related to the employment generation, whereas technology is considered as a dummy variable that is constructed on the basis that a firm is using the advance technology or not as shown in Table 3.

Firm age represented the experience of the firm in the production process and is construed as to how many years a firm spend in current business before using the Islamic finance. The empirical result showed that firm age has a significant but inverse association with 
employment generation as shown in Table 2. The results are consistent with other studies (Banerjee, 2016; Liu, 2018).

Business size (BS) has significant but inverse relationship with employment generation (Birch 1981; Liu, 2018) in Punjab. Results indicate that employment creation is inversely related with firm size. As firms grow with the passage of time, they specialized in production process while their size to employment ratio decreases. In Slovenia, it was noticed that new firms reveal more employment (Banerjee, 2016).

TABLE 4

Results of Multiple linear Regression Model

\begin{tabular}{|c|c|c|c|c|c|c|c|}
\hline \multirow[t]{2}{*}{ Model } & \multicolumn{2}{|l|}{$\begin{array}{l}\text { Un standardized } \\
\text { Coefficients }\end{array}$} & \multirow{2}{*}{$\begin{array}{c}\text { Standardized } \\
\text { Coefficients } \\
\text { Beta }\end{array}$} & \multirow[t]{2}{*}{$t$} & \multirow[t]{2}{*}{ Sig. } & \multicolumn{2}{|c|}{ Collinearity Statistics } \\
\hline & B & Std. Error & & & & Tolerance & VIF \\
\hline (Constant) & 6.205 & 1.887 & & 3.289 & 0.001 & & \\
\hline Assets Formation & 0.302 & 0.037 & 0.481 & 8.241 & 0.000 & 0.957 & 1.045 \\
\hline Technology & -8.999 & 1.744 & -0.309 & -5.159 & 0.000 & 0.910 & 1.099 \\
\hline Firm age & -0.136 & 0.066 & -0.121 & -2.049 & 0.042 & 0.929 & 1.076 \\
\hline Business Size & -5.616 & 1.634 & -0.201 & -3.437 & 0.001 & 0.953 & 1.049 \\
\hline
\end{tabular}

Source: Primary data collected by author

\section{Employment Generation and Assets Growth}

Islamic financing system is said to be paying more return on assets as compared to the conventional system (Azhar \& Afandi, 2003). There is a medium level relationship among the assets and the employment generation.. There was only one ( $0.5 \%$ of total) firm/borrower that shifted to negative assets and employment generation after getting the Islamic finance (Table 5). Assets formation and employment has positive and direct relationship with each other (Table 4). When assets formation of firms getting Islamic finance from Islamic banks increased, the employment in those firms also increased. A positive relationship between assets formation and employment was also noticed in India (Yadav, \& Mishra, 1980).

Data revealed that employment generation by firms utilizing Islamic finance was strongly related with assets growth of the firm. Majority of the firms (86 percent) which increased their assets with Islamic finance created more jobs in Punjab (Table 5). In another study, it was observed that employment generation was more with repeated loans as compared to first loan (Rabbani, \& Suleiman 2005). It was envisaged in Bangladesh that Islamic finance supported self-employment (Nabi, Islam, Bakar, \& Nabi, 2018). 
TABLE 5

Employment and Assets Growth after Utilizing Islamic Finance

\begin{tabular}{llllll}
\hline \hline & \multicolumn{3}{c}{ Assets Formation } & \\
\cline { 3 - 5 } & & -ve Change & No change & +ve Change & Total \\
\hline Employment & -ve change & $1(0.5)$ & $10(4.9)$ & $78(37.9)$ & $89(43.2)$ \\
generation & no change & $1(0.5)$ & $8(3.9)$ & $16(7.8)$ & $25(12.1)$ \\
& +ve change & $0(0)$ & $9(4.4)$ & $83(40.3)$ & $92(44.7)$ \\
& Total & $2(1)$ & $27(13)$ & $177(86)$ & $206(100)$ \\
\hline \hline
\end{tabular}

Source: Authors own calculations, Note: figure in parenthesis are percentages Goodness of Fit Test

Goodness of fit of a model explains that how a statistical model is good fitted between observed values and expected values. To check the better performance of fitted model, VIF (Variance inflation Factor) was used, and value $(<4)$ shows that there is no multicolinearity among the repressors' or control variables.

TABLE 6

Analysis of Variance (ANOVA) of the Model

\begin{tabular}{llllll}
\hline \hline Model & Sum of Squares & df & Mean Square & F & Sig. \\
\hline Regression & 13859.251 & 4 & 3464.813 & 26.79 & $.000^{\mathrm{b}}$ \\
Residual & 25866.087 & 200 & 129.330 & & \\
Total & 39725.338 & 204 & & & \\
\hline
\end{tabular}

a. Dependent Variable: Employment generation

b. Predictors: (Constant), Experience, Business Size, Assets generation, Technology

The overall performance of the model, was assessed from the F-value which indicated strongly significant results in the analysis of variance (ANOVA) Table 6, which is 26.79 and the $p$-value is less than 0.05 .

\section{CONCLUSION}

The study was planned to analyze the role of finance extended by the Islamic banks on employment generation in the province of Punjab, Pakistan. Firm behavior utilizing Islamic finance was analyzed on the basis of business size, assets formation, firm age and technological adoption. Results of model revealed that assets formation had positive relationship with employment generation while firm age, firm size and technology had inverse relationship with employment generation. This indicated the importance of assets formation through financial support of borrowers in employment generation.

It is, therefore, recommended that Islamic Financial institutions in the country may pay more emphasis on assets formation while extending Islamic finance to their clients. Furthermore, the State Bank of Pakistan may enhance focus on financing of SMEs carrying proposals of more assets formation, by Islamic financial institutions, as a tool to meet the challenge of reducing unemployment in the country. 


\section{REFERENCES}

Adelino, M., Ma, S., \& Robinson, D. (2017). Firm age, investment opportunities, and job creation. The Journal of Finance, 72(3), 999-1038. doi: https://doi.org/10.1111/jofi.12495

Aghion, P., Akcigit, U., Cagé, J., \& Kerr, W. R. (2016). Taxation, corruption, and growth. European Economic Review, 86, 24-51.

doi: https://doi.org/10.1016/j.euroecorev.2016.01.012

Ajaga, E., \& Nunnenkamp, P. (2008). Inward FDI, value added and employment in US states: A panel cointegration approach. Working paper no. 1420, Kiel Institute for the World Economy, Kiel, Germany.

Aliero, H. M., Ibrahim, S. S., \& Shuaibu, M. (2013). An empirical investigation into the relationship between financial sector development and unemployment in Nigeria. Asian Economic and Financial Review, 3(10), 1361-1370.

Atkinson, J., \& Storey, D. J. (2016). Employment, the small firm and the labour market. London, UK: Routledge.

Ayub, M. (2018). Maqasid realisation in Islamic finance: Components of framework for measurement index. Journal of Islamic Business and Management, 8(1), 1-9. doi: https://doi.org/10.26501/jibm/2018.0801-001

Azhar Rosly, S., \& Afandi Abu Bakar, M. (2003). Performance of Islamic and mainstream banks in Malaysia. International Journal of Social Economics, 30(12), 1249-1265. doi: https://doi.org/10.1108/03068290310500652

Banerjee B., Jesenko M. (2014). Dynamics of firm-level job flows in Slovenia, 1996-2011. Comparative Economic Studies, 56(1), 77-109.

doi: https://doi.org/10.1057/ces.2013.30

Banerjee, B. (2016). The role of firm size and firm age in employment growth: Evidence for Slovenia, 1996-2013. Available from: https://bit.ly/2nkN9hg

Bayar, Y. (2016). Financial development and unemployment in emerging market economies. Scientific Annals of Economics and Business, 63(2), 237-245.

doi: https://doi.org/10.1515/saeb-2016-0119

Birch, D. L. (1981). Who creates jobs? The Public Interest, 65(9), 3-14.

Burns, P. (2016). Entrepreneurship and small business. New York, NY: Palgrave Macmillan Limited.

Christiano, L. J., Eichenbaum, M. S., \& Trabandt, M. (2016). Unemployment and business cycles. Econometrica, 84(4), 1523-1569. doi: https://doi.org/10.3982/ecta11776

Effendi, K. A., \& Yuniarti, R. D. (2018). Credit risk and macroeconomics of Islamic Banking in Indonesia. Journal of Accounting, Finance and Auditing Studies, 4(2), 1-13. doi: https://doi.org/10.5220/0007077400920095

Government of Pakistan. (2014). Economic survey of Pakistan 2013-2014. Economic Advisor's Wing, Finance Division, Ministry of finance. Government of Pakistan, Islamabad, Pakistan. 
Government of Pakistan. (2015). Labour force surveys 2014-15. Statistics Division, Pakistan Bureau of Statistics, Government of Pakistan, Islamabad, Pakistan.

Government of Pakistan. (2016). Economic survey of Pakistan 2015-16. Economic Advisors Wing, Finance Division, Ministry of finance, Government of Pakistan, Islamabad, Pakistan.

Government of Pakistan. (2017). Economic survey of Pakistan 2016-17. Economic Advisors Wing, Finance Division, Ministry of finance, Government of Pakistan, Islamabad, Pakistan.

Government of Pakistan. (2018). Economic survey of Pakistan 2017-18. Economic Advisors Wing, Finance Division, Ministry of finance, Government of Pakistan, Islamabad, Pakistan.

Government of Pakistan. (2019). Economic survey of Pakistan 2018-19. Economic Advisors Wing, Finance Division, Ministry of finance, Government of Pakistan, Islamabad, Pakistan.

Iqbal, M., \& Amad, A. (2005). Islamic finance and economic development. New York, NY: Palgrave Macmillan.

Kimuyu, P., \& Omiti, J. (2000). Institutional impediments to access to credit by micro and small scale enterprises in Kenya. Nairobi, Kenya: Institute of Policy Analysis and Research.

Kim, D. H., Chen, T. C., \& Lin, S. C. (2018). Finance and unemployment: New panel evidence. Journal of Economic Policy Reform, 4(5), 1-18. doi: https://doi.org/10.1080/17487870.2018.1451750

Liu, Y. (2018). Firm age, size, and employment dynamics: Evidence from Japanese firms. Discussion papers 18006, Research Institute of Economy, Trade and Industry, Tokyo, Japan.

Mas-Verdú, F., Ribeiro-Soriano, D., \& Roig-Tierno, N. (2015). Firm survival: The role of incubators and business characteristics. Journal of Business Research, 68(4), 793-796. doi: https://doi.org/10.1016/j.jbusres.2014.11.030

Nabi, M. G., Islam, M. A., Bakar, R., \& Nabi, R. (2018). Islamic microfinance as a tool of financial inclusion in Bangladesh. Available from: https://bit.ly/2nkTUj8

Nunley, J. M., Pugh, A., Romero, N., \& Seals Jr, R. A. (2016). College major, internship experience, and employment opportunities: Estimates from a résumé audit. Labour Economics, 38, 37-46. doi: https://doi.org/10.1016/j.labeco.2015.11.002

Peters, R. H., \& Taylor, L. A. (2017). Intangible capital and the investment-q relation. Journal of Financial Economics, 123(2), 251-272. doi: https://doi.org/10.1016/j.jfineco.2016.03.011

Rabbani, M., \& Suleiman, M. (2005). Financing smes and its effect on employment generation: A study of brac banks SME lending. Available from: https://bit.ly/2nldpbi

Schmitz, H. (2018). Technology and employment practices in developing countries. London, UK: Routledge.

Selim, M., \& Hassan, M. K. (2019). Interest-free monetary policy and its impact on inflation and unemployment rates. International Journal of Islamic Finance, 11(1), 46-61. doi: https://doi.org/10.1108/ijif-06-2018-0065 
Shabbir, G., Anwar, S., Hussain, Z., \& Imran, M. (2012). Contribution of financial sector development in reducing unemployment in Pakistan. International Journal of Economics and Finance, 4(1), 260-268.

doi: https://doi.org/10.5539/ijef.v4n1p260

Usmani, M. T. (2007). An introduction to Islamic Finance. Karachi, Pakistan: Maktaba Ma'ariful Qur'an.

Yadav, H., \& Mishra, C. S. (1980). Impact of the tribal development programmes on employment, income and asset formation in Bastar district of Madhya Pradesh. Indian Journal of Agricultural Economics, 35(1740), 69-73.

Zafar, A., \& Mustafa, S. (2017). SMEs and its role in economic and socio-economic development of Pakistan. International Journal of Academic Research in Accounting, Finance and Management Sciences, 6(4), 56-60. doi: https://doi.org/10.6007/ijarafms/v7$\mathrm{i} 4 / 3484$ 